\title{
Editorial
}

\section{5-Hydroxyvitamin D assay standardisation and vitamin D guidelines paralysis}

\section{Overview: vitamin D guidelines paralysis}

Vitamin D guidelines development is in a state of paralysis. There is an outward sign of a growing consensus between the two groups of nations: (1) the UK and the Netherlands with (2) Australia-New Zealand, European Union (EU) and the USA in how to define the lower limit of vitamin D adequacy based on serum total 25-hydroxyvitamin D $(25(\mathrm{OH}) \mathrm{D})$ concentration $^{(1)}$ (Fig. 1), that is, the sum of serum $25(\mathrm{OH})_{2}$ and $25(\mathrm{OH}) \mathrm{D}_{3}$ concentrations. But the two groups do not agree if there are data to support defining additional vitamin D physiological states, e.g. insufficiency, sufficiency and toxicity based on $25(\mathrm{OH}) \mathrm{D}$ concentrations. Moreover, those national recommendations conflict with a third set of recommendations from non-governmental medical societies and organisations $^{(1)}$, for example, the Endocrine Society, with no prospect for resolving the differences among the three approaches ${ }^{(1,2)}$. Given the wealth of vitamin D research, it could be expected that the controversy would be resolved and consensus reached. Why has this not occurred?

To understand this situation, we need to understand the requirements for making and revising guidelines and policies that result from those guidelines. Understanding those requirements leads to a rather straightforward conclusion: Making and revising guidelines requires $25(\mathrm{OH}) \mathrm{D}$ data from rigorously conducted research and nationally representative surveys ${ }^{(3,4)}$. In addition, nationally representative survey data are required to accurately and precisely assess the current state of vitamin D status in the population by person, season and geographical location, and to monitor changes over time in order to develop rational guidelines and associated policies and revise them over time ${ }^{(5,6)}$. But variability of $25(\mathrm{OH}) \mathrm{D}$ assays thwarts attempts to resolve the controversy ${ }^{(7)}$.

Variability of $25(\mathrm{OH}) \mathrm{D}$ assays is widely recognised ${ }^{(7-10)}$. As such, only standardised $25(\mathrm{OH}) \mathrm{D}$ data provide the necessary level of accuracy and precision essential to the process of developing evidence-based vitamin D guidelines and policies $^{(3-6)}$. In the last 10 years, enormous progress has been made in collecting nationally representative survey data that meet those requirements ${ }^{(11-16)}$, but despite this progress, we remain woefully behind in generating the vitamin D research data necessary to break out of the paralysis.
Thus, we have at a minimum three basic approaches for defining different states of vitamin D status, and no way to determine which is most appropriate. The goals of this Commentary are to describe the origins of the problem and to propose a set of recommendations based on work of the Vitamin D Standardization Program (VDSP) that may provide a way forward in developing rational vitamin D status guidelines.

\section{Origin of vitamin D guidelines, 25(OH)D assay variability and policy paralysis}

The UK appears to be the first country to have adopted serum 25(OH)D cut-points for defining vitamin D status. In 1991, the UK Committee on Medical Aspects of Food and Nutrition Policy (COMA) Dietary Reference Values (DRV) report stated that 'Plasma 25-OHD concentrations in rickets range from not detectable to about $8 \mathrm{ng} / \mathrm{ml}^{(17)}$. That appears to be the first recommended cut-off for 25(OH)D. The quoted source was a 1976 paper by Arnaud et al. ${ }^{(18)}$ reporting serum 25(OH)D concentrations ranging between approximately 8 and $20 \mathrm{ng} / \mathrm{ml}$ in nine cases of rickets (Fig. 2). As a result, it appears that the UK DRV 1991 Committee acted conservatively in picking an $8 \mathrm{ng} / \mathrm{ml}(20 \mathrm{nmol} / \mathrm{l}) 25(\mathrm{OH}) \mathrm{D}$ cut-point. In the 1998 UK COMA report, the $25(\mathrm{OH}) \mathrm{D}$ cut-point was raised to $10 \mathrm{ng} / \mathrm{ml}(25 \mathrm{nmol} / \mathrm{l})^{(19)}$. In this case, the quoted source was a 1986 paper by Grindulis et al. ${ }^{(20)}$. It is not clear why the value was increased to $10 \mathrm{ng} / \mathrm{ml}$ ( $25 \mathrm{nmol} / \mathrm{l})$, but it may have been as simple as 10 is a round number easy for physicians to remember. The recent 2016 UK Scientific Advisory Committee on Nutrition (SACN) retained the 1998 COMA $10 \mathrm{ng} / \mathrm{ml}(25 \mathrm{nmol} / \mathrm{l})$ concentration to define the lower limit of adequacy, 'based on evidence suggesting risk of rickets and osteomalacia is increased at concentrations below this level' ${ }^{,(21)}$. Notably, variability within and among 25(OH)D assays was cited as an important limitation 'for interpretation of studies that have examined the relationship between serum 25(OH)D concentration and health outcomes'. ${ }^{(21)}$.

Concern about $25(\mathrm{OH}) \mathrm{D}$ assay variability is not a new problem. The problem was first reported in 1983$1984^{(22-24)}$ and in many publications since that time ${ }^{(25,26)}$. 


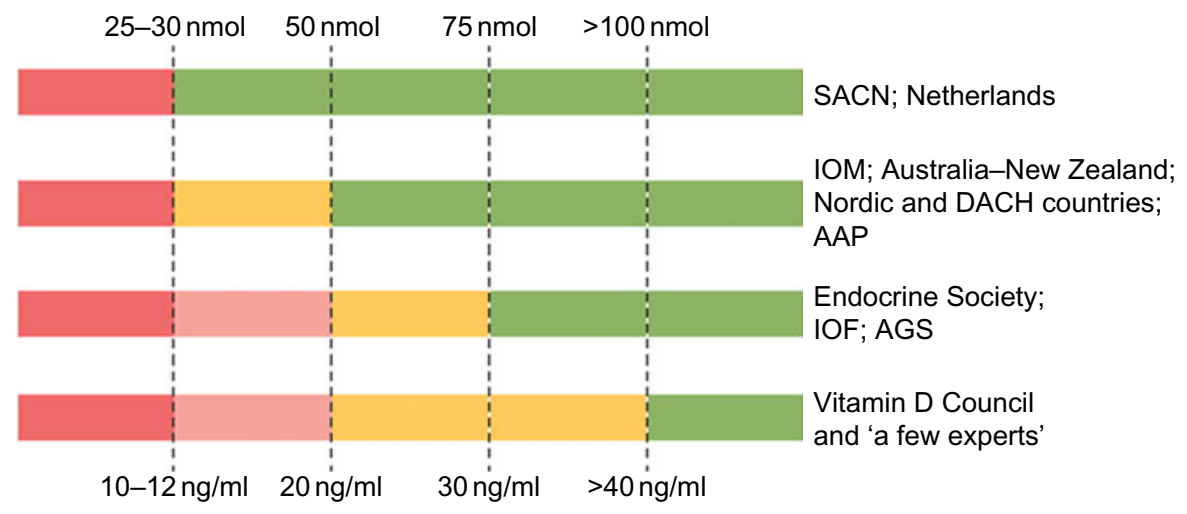

Fig. 1 Recommendations for interpreting serum levels of 25-hydroxyvitamin D. 'A schematic representation of how different agencies and countries interpret serum levels of 25 -hydroxyvitamin $D$ is shown. Colour code: red denotes a state of severe deficiency (danger) that has to be corrected without exception; orange denotes a state of mild deficiency (modest concern), in which intervention is desirable; green denotes a state of sufficient supply that does not benefit from additional supplementation. AAP, American Academy of Pediatrics; AGS, American Geriatrics Society; DACH, Deutschland (Germany, Austria and Confoederatio Helvetica (Switzerland); IOF, International Osteoporosis Foundation; IOM, Institute of Medicine; SACN, Scientific Advisory Committee on Nutrition.' Source: Bouillon $^{(1)}$

As a result, the Vitamin D External Quality Assessment Scheme (DEQAS) was introduced in 1989 to improve the reliability of $25(\mathrm{OH}) \mathrm{D}$ assays ${ }^{(26)}$. In 2013 , DEQAS became an accuracy-based external quality assessment scheme (EQAS) with Joint Committee for Traceability in Laboratory Medicine (JCTLM)-approved reference measurement procedures from the National Institute for Standards and Technology (NIST) and the Centers for Disease Control and Prevention (CDC) being used to provide the target values, that is, true $25(\mathrm{OH}) \mathrm{D}$ concentration, for serum samples used in DEQAS ${ }^{(27,28)}$.

Currently, there are primarily two basic types of assays in use: (1) automated immunoassays, which are commercially developed and marketed; and (2) chromatographybased assays, which are primarily laboratory-developed using HPLC or LC-MS/MS ${ }^{(25,29,30)}$. Trends in the performance of assays used by participating laboratories have been tracked since the initiation of DEQAS ${ }^{(26)}$.

Recent DEQAS results (January 2019) document that $25(\mathrm{OH}) \mathrm{D}$ assay variability persists among the ten assays most commonly used by participating laboratories (Table 1). Clearly, mean bias, defined as the percentage difference from the true concentration, varies by sample within an assay, and there is enormous variability around the mean for all the assays. Moreover, there is a great deal of variability among the different assays. HPLC and especially LC-MS/MS assays are often assumed to be the gold standard; however, results in Table 1 demonstrate that a great deal of variability exists among the laboratories using them. Similar results were found in the recent analysis of data from the College of American Pathologists (CAP) Accuracy-Based Vitamin D (ABVD) survey ${ }^{(31)}$. Thus, using a chromatography-based assay and participating in an external quality assessment programme does not assure that ' $25(\mathrm{OH}) \mathrm{D}$ ' results from research studies or national surveys are accurate ${ }^{(31,32)}$. This is an essential point: without

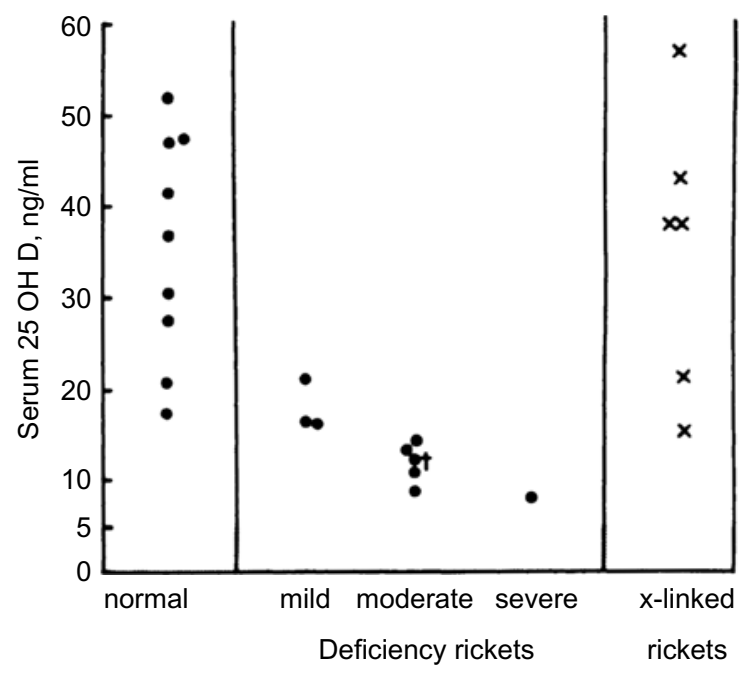

Fig. 2 Distribution of serum 25-hydroxyvitamin D values in normal and rachitic children, aged 2 months -6 years (Source: Arnaud et al. ${ }^{(18)}$ )

*'Patient No. 7 represents 25-OH-D; this patient had received 400 IU of vitamin D2 daily'.

documented assay standardisation, it cannot be assumed that just because a laboratory uses an HPLC or LC-MS/MS assay the results are either accurate or precise.

Following the UK, the USA, in 1997, adopted a 25(OH)D concentration $<11 \mathrm{ng} / \mathrm{ml}(27.5 \mathrm{nmol} / \mathrm{ml})$ as the level consistent with vitamin D deficiency in infants, neonates and young children(33). The quoted source was a paper by Specker et al. ${ }^{(34)}$. The US and Canada governments then co-sponsored an updated DRI review of calcium and vitamin D in $2011^{(35)}$. The $25(\mathrm{OH}) \mathrm{D}$ cut-off to define persons at risk of vitamin $\mathrm{D}$ deficiency was changed from $<11$ to $<12 \mathrm{ng} / \mathrm{ml}$ (30 mnol/1), most likely to make it a round number to fit in with the IOM 2011's definition of the 25(OH)D concentration consistent with both the average vitamin $\mathrm{D}$ requirement, that is, $16 \mathrm{ng} / \mathrm{ml}(40 \mathrm{nmol} / \mathrm{l})$, and the 
Table 1 Mean bias from the 'true' sample concentration for the ten most commonly used assay platforms of the laboratories participating in the Vitamin D External Quality Assessment Scheme (DEQAS)*

\begin{tabular}{|c|c|c|c|c|c|c|c|c|c|c|c|}
\hline \multirow[b]{3}{*}{ Assay } & \multirow[b]{3}{*}{$\begin{array}{l}\text { Labs } \\
(n)\end{array}$} & \multicolumn{2}{|c|}{$\begin{array}{l}\text { DEQAS } \\
\text { sample } 550\end{array}$} & \multicolumn{2}{|c|}{$\begin{array}{l}\text { DEQAS } \\
\text { sample } 546\end{array}$} & \multicolumn{2}{|c|}{$\begin{array}{c}\text { DEQAS } \\
\text { sample } 549\end{array}$} & \multicolumn{2}{|c|}{$\begin{array}{l}\text { DEQAS } \\
\text { sample } 547\end{array}$} & \multicolumn{2}{|c|}{$\begin{array}{c}\text { DEQAS } \\
\text { sample } 548\end{array}$} \\
\hline & & $\mathrm{CDC}+\mathrm{s}$ & $4.5 \mathrm{nmol} / \mathrm{l}$ & $\mathrm{CDC}+5$ & $2.1 \mathrm{nmol} / \mathrm{l}$ & $\mathrm{CDC}+6$ & $1.9 \mathrm{nmol} / \mathrm{l}$ & $\mathrm{CDC}+7$ & $1.3 \mathrm{nmol} / \mathrm{l}$ & $\mathrm{CDC}+8$ & $7.0 \mathrm{nmol} / \mathrm{l}$ \\
\hline & & $\begin{array}{c}\text { Mean } \\
\text { bias } \\
(\%)\end{array}$ & $95 \% \mathrm{Cl}$ & $\begin{array}{c}\text { Mean } \\
\text { bias } \\
(\%)\end{array}$ & $95 \% \mathrm{Cl}$ & $\begin{array}{c}\text { Mean } \\
\text { bias } \\
(\%)\end{array}$ & $95 \% \mathrm{Cl}$ & $\begin{array}{c}\text { Mean } \\
\text { bias } \\
(\%)\end{array}$ & $95 \% \mathrm{Cl}$ & $\begin{array}{c}\text { Mean } \\
\text { bias } \\
(\%)\end{array}$ & $95 \% \mathrm{Cl}$ \\
\hline Abbott Architect New & 64 & -7 & $-24,9$ & -4 & $-15,6$ & -2 & $-12,7$ & -1 & $-12,10$ & 7 & $-3,17$ \\
\hline Bechman Unicel & 35 & 6 & $-38,50$ & -8 & $-31,15$ & -11 & $-35,12$ & -1 & $-22,20$ & -2 & $-20,17$ \\
\hline DiaSorin Liaison Total & 185 & 18 & $-4,41$ & 7 & $-10,25$ & 10 & $-6,26$ & 4 & $-12,20$ & 7 & $-9,24$ \\
\hline HPLC & 17 & 7 & $-52,66$ & -1 & $-41,40$ & 8 & $-64,80$ & 7 & $-42,57$ & 4 & $-37,46$ \\
\hline IDS-iSYS & 31 & 0 & $-44,44$ & 5 & $-23,33$ & 2 & $-14,18$ & -5 & $-25,15$ & 1 & $-16,18$ \\
\hline IDS-SYS New & 17 & 4 & $-25,33$ & 6 & $-25,37$ & 7 & $-17,30$ & 5 & $-19,28$ & 7 & $-16,30$ \\
\hline LC-MS/MS & 143 & -1 & $-23,21$ & 0 & $-20,20$ & 1 & $-18,20$ & 1 & $-18,20$ & 2 & $-17,21$ \\
\hline Roche Total $25 \mathrm{OHD}$ & 76 & 5 & $-24,35$ & 4 & $-16,24$ & 1 & $-17,18$ & 12 & $-11,35$ & 10 & $-10,31$ \\
\hline Roche Vitamin D Total II & 62 & 6 & $-21,33$ & -5 & $-19,9$ & -2 & $-17,13$ & -1 & $-13,11$ & -2 & $-14,10$ \\
\hline $\begin{array}{l}\text { Siemens ADVIA } \\
\text { Centuar }\end{array}$ & 48 & 34 & $-15,83$ & 12 & $-16,40$ & 8 & $-18,33$ & 4 & $-23,31$ & 6 & $-18,31$ \\
\hline
\end{tabular}

*January 2019 distribution for samples 546-550. Results are displayed by lowest to highest serum 25-hydroxyvitamin D concentrations of DEQAS samples. Data source: DEQAS Laboratory Report for January 2019 distribution (http://www.deqas.org/).

†CDC reference measurement procedure true concentration target value; Mineva et al. ${ }^{(28)}$

requirements of approximately $98 \%$ of the population, that is, $20 \mathrm{ng} / \mathrm{ml}(50 \mathrm{nmol} / \mathrm{l}) .25(\mathrm{OH}) \mathrm{D}$ cut-points were based on relationships to markers of bone health, and there was no single quoted source for the suggested cut-points.

Thus, the IOM 2011 guidelines were consistent with the UK guidelines and IOM 1997 in defining the lower limit of adequacy, but it was more expansive in setting $25(\mathrm{OH}) \mathrm{D}$ levels to define inadequacy $12-20 \mathrm{ng} / \mathrm{ml}(30-50 \mathrm{nmol} / \mathrm{l})$, sufficiency $20-30 \mathrm{ng} / \mathrm{ml}(50-75 \mathrm{nmol} / \mathrm{l})$, no added benefit $30-50 \mathrm{ng} / \mathrm{ml}(75-125 \mathrm{nmol} / \mathrm{l})$ and possible harm $>50 \mathrm{ng} / \mathrm{ml}$ ( $>125 \mathrm{nmol} / \mathrm{l})$ such that we can speak of overlapping but non-congruent sets of national guidelines ${ }^{(1)}$ (Fig. 1). Moreover, the authors of the report commented that 'Currently, different assays for the determination of serum 25OHD levels are in use, and they provide disparate results. In turn, reported measures are confounded by the need to understand the assay used and research reports contain results that are not easily compared. The role of standard reference materials and interlaboratory collaboration is an important aspect of overcoming the challenges that the assay methodologies present'(35). In short, this report acknowledged that without assay standardisation, results from different studies are not comparable and, ideally, they should not be pooled to develop consensus results.

National committees like those in the UK and USA appropriately tend to be very conservative. Once guidelines have been established, they are re-evaluated only when there is sufficient new data ${ }^{(36)}$ and updated only when that data are irrefutable and there is consensus supporting change. No government agency wants to face a situation of having to retract one set of guidelines and replace it with a new set. With such a change, there is a loss of confidence in the entire process by the public at large, clinicians and scientists, all of which can result in the loss of necessary political support, that is, money, to develop and revise guidelines. Moreover, government laws, regulations, rules and programmes may be based on the guidelines, and changing and then unravelling existing guidance would not only result in lost confidence but an enormous cost in money and resources. As a result, once deficiency was defined in IOM 1997, it became the fulcrum around which future guidelines would revolve as seen in IOM 2011. An important issue that was hinted at in both IOM 2011 and SACN 2016 reports is that without assay standardisation further revision of $25(\mathrm{OH}) \mathrm{D}$ cut-points would be difficult, that is, paralysis.

Following the release of IOM 2011 guidelines, several other countries and medical societies released vitamin D guidelines (Fig. 1, Table 2). National agencies, more often than not, look to the guidelines of other countries when setting their own. The tendency is for national agencies to adopt the guidelines of other countries. In this case, the Nordic countries ${ }^{(37)}$, the Swiss Federal Commission on Nutrition $^{(38)}$ along with the EFSA ${ }^{(39)}$ adopted IOM 2011 guidelines or IOM 2011-like guidelines for interpreting $25(\mathrm{OH}) \mathrm{D}$ concentrations, while the Netherlands, being a bit more conservative, adopted the UK 1998 COMA recommendations to define a $25(\mathrm{OH}) \mathrm{D}$ concentration of $10 \mathrm{ng} / \mathrm{ml}$ $(25 \mathrm{nmol} / \mathrm{l})$ as the level at which risk of rickets and osteomalacia increases for persons aged $0-70$ years ${ }^{(40)}$. All these groups have adopted guidelines consistent with the conservative spirit of the UK DRV 1991 and IOM 2011 guidelines. That is, they define a serum $25(\mathrm{OH}) \mathrm{D}$ concentration of $25-30 \mathrm{nmol} / \mathrm{l}(10-12 \mathrm{ng} / \mathrm{ml})$ as the lower limit of adequacy an indicator of high risk of vitamin D deficiency (Fig. 1, Table 2). In addition, several organisations ${ }^{(41-51)}$, including the Global Consensus Recommendations on Prevention and Management of Nutritional Rickets ${ }^{(51)}$ (Table 2), have adopted guidelines consistent with IOM 2011 that define cut-points for insufficiency, sufficiency and possible harm. 
Table 2 Selected ${ }^{*}$ recommendations for interpreting serum total 25-hydroxyvitamin D concentrations by type of committee, year of publication and consistency with UK DRV 1991, IOM2011 or Endocrine Society 2012 recommendations

\begin{tabular}{|c|c|c|}
\hline Type of committee & Year of publication & Consistent with \\
\hline \multicolumn{3}{|l|}{ Governmental } \\
\hline UK DRV ${ }^{(17)}$ & 1991 & UK DRV 1991 \\
\hline US IOM${ }^{(33)}$ & 1997 & UK DRV 1991 \\
\hline UK COMA ${ }^{(19)}$ & 1998 & UK DRV 1991 \\
\hline The Netherlands ${ }^{(40)}$ & 2012 & UK DRV $1991 \dagger$ \\
\hline UK SACN(21) & 2016 & UK DRV 1991 \\
\hline US IOM(35) & 2011 & US IOM 2011 \\
\hline NORDIC ${ }^{(37)}$ & 2012 & US IOM 2011 \\
\hline Swiss Federal Commission for Nutrition ${ }^{(38)}$ & 2012 & US IOM 2011 \\
\hline European Food Safety Authority ${ }^{(39)}$ & 2016 & US IOM 2011 \\
\hline \multicolumn{3}{|l|}{ Non-governmental/medical societies } \\
\hline Lawson Wilkins Pediatric Endocrine Society $(41)$ & 2008 & US IOM 2011 \\
\hline German, Austrian, \& Swiss Nutrition Societies (DACH) ${ }^{(42)}$ & 2012 & US IOM 2011 \\
\hline Australia/New Zealand $(43,44)$ & $2012 / 2013$ & US IOM 2011 \\
\hline British Paediatric ${ }^{(45)}$ & 2012 & US IOM 2011 \\
\hline French Society of Pediatrics ${ }^{(46)}$ & 2012 & US IOM 2011 \\
\hline Spanish Association of Pediatrics ${ }^{(47)}$ & 2012 & US IOM 2011 \\
\hline European Society for Paediatric Gastroenterology, Hepatology and Nutrition ${ }^{(48)}$ & 2013 & US IOM 2011 \\
\hline American Academy of Pediatrics ${ }^{(49,50)}$ & 2008,2014 & US IOM 2011 \\
\hline Global Consensus Recommendations ${ }^{(51)}$ & 2016 & US IOM 2011 \\
\hline Canadian Paediatric Society ${ }^{(53)}$ & 2007 & Endocrine Society \\
\hline International Osteoporosis Foundation ${ }^{(54)}$ & 2010 & Endocrine Society \\
\hline \multicolumn{3}{|l|}{ Scientific Advisory Council of Osteoporosis Canada(55) } \\
\hline Endocrine Society ${ }^{(52)}$ & 2011 & Endocrine Society \\
\hline Central Europe ${ }^{(56)}$ & 2013 & Endocrine Society \\
\hline Society for Adolescent Health and Medicine ${ }^{(57)}$ & 2013 & Endocrine Society \\
\hline American Geriatrics Society Workshop ${ }^{(58)}$ & 2014 & Endocrine Society \\
\hline National Osteoporosis Foundation ${ }^{(59)}$ & 2014 & Endocrine Society \\
\hline Vitamin D Council( ${ }^{(60)}$ & 2015 & Endocrine Society \\
\hline United Arab Emirates ${ }^{(61)}$ & 2016 & Endocrine Society \\
\hline Japanese Medical Societies ${ }^{(62)} \dagger$ & 2017 & Endocrine Society $\ddagger$ \\
\hline Italian Pediatric Society ${ }^{(63)}$ & 2018 & Endocrine Society \\
\hline
\end{tabular}

${ }^{*}$ Adapted, in part, from Bouillon ${ }^{(1)}$ and Saggese et al. ${ }^{(63)}$.

†Expert panel supported by the research programme of intractable diseases; Ministry of Health, Labour and Welfare, Japan; the Japanese Society for Bone and Mineral Research; and the Japan Endocrine Society. It is not clear if this was a 'governmental' set of guidelines.

†Recommendations for: ages 0-70: serum $25(\mathrm{OH}) \mathrm{D}$ level $>12 \mathrm{ng} / \mathrm{ml}(30 \mathrm{nmol} / \mathrm{l})$; and age $>70$ : risk of bone fractures and serum $25(\mathrm{OH}) \mathrm{D}>20 \mathrm{ng} / \mathrm{ml}(50 \mathrm{nmol} / \mathrm{l})$.

Does this indicate a developing consensus among health agencies? Possibly, but we believe it likely indicates conformity rather than evidence-based consensus.

In 2011 a third distinct set of guidelines - 'Evaluation, Treatment, and Prevention of Vitamin D Deficiency: An Endocrine Society Clinical Practice Guideline (emphasis added)' - was released by the Endocrine Society ${ }^{(52)}$, and while they were quite similar to the 2007 guidelines released by the Canadian Paediatric Society ${ }^{(53)}$ (Table 2), they have come to be the focus of opposition to the UK DRV 1991 and IOM 2011 guidelines. Several medical societies and non-governmental organisations have adopted the Endocrine Society guidelines ${ }^{(54-63)}$. The Endocrine Society set the $25(\mathrm{OH}) \mathrm{D}$ concentration to define deficiency, insufficiency, sufficiency and possible harm at $<20 \mathrm{ng} / \mathrm{ml} \quad(50 \mathrm{nmol} / \mathrm{l}), 21-29 \mathrm{ng} / \mathrm{ml}$ (52.5-72.5), 30-100 ng/ml (75-250 nmol/l) and $>100 \mathrm{ng} / \mathrm{ml}$ (>250 nmol/1), respectively ${ }^{(52)}$ based on the 2007 paper by Holick $^{(64)}$.

The Endocrine Society guidelines were quite different from anything proposed by the UK DRV 1991 or IOM 2011 guidelines (Table 3). They set off a firestorm of debate between the authors of the Endocrine Society and the authors of IOM 2011 guidelines that has continued ever since.
But there is even more confusion. The Endocrine Society stated that their guidelines were designed for clinical practice, while the IOM 2011 and later UK SACN 2016 demurred by stating that their guidelines were not for use in clinical practice but were public health guidelines for the general healthy non-diseased population ${ }^{(21,35,52)}$. We find it difficult to understand how a government agency can define interpretive guidelines for $25(\mathrm{OH}) \mathrm{D}$ - especially to define vitamin D deficiency - and not have them be clinically relevant. This emphasises the point that public health and clinical guidelines both need to revolve around identical sets of interpretive cut-points; otherwise there will be chaos and confusion among government agencies, physicians and the general public - as currently exists.

Given the sharp distinctions between the IOM 2011 and Endocrine Society guidelines, how can we go about determining the 'best' or 'most appropriate' cut-points given our current state of knowledge (Table 3)? Will meta-analyses solve the problem? There are an ever-increasing number published every year (Fig. 3), and yet we do not appear to be any closer to a resolution to this dilemma.

The fundamental reason why meta-analyses of the currently available data will not resolve the problem is that, 
Table 3 Comparison of Institute of Medicine ${ }^{(35)} v$. Endocrine Society ${ }^{(52)}$ cut-points for serum total 25-hydroxyvitamin D (nmol/l)

\begin{tabular}{lccc}
\hline & IOM & & Endocrine Society \\
\cline { 2 - 3 } Interpretation & Serum total & $25(\mathrm{OH}) \mathrm{D}(\mathrm{ng} / \mathrm{ml})^{*}$ \\
\hline Deficient & $<12$ & $<20$ \\
Insufficient & $12-20$ & $21-29$ \\
Sufficient & $20-30$ & $30-100$ \\
No added benefit & $30-50$ & $>100$ \\
Possible harm & $>50$ & \\
\hline
\end{tabular}

${ }^{*} \mathrm{nmol} / \mathrm{l}=\mathrm{ng} / \mathrm{ml} \times 2.5$.

without assay standardisation, meta-analyses based on $25(\mathrm{OH}) \mathrm{D}$ concentrations are quite simply uninterpretable as it is impossible to pool the disparate results from different studies in any reasonable fashion. Currently, to our knowledge, there are only three meta-analyses based on standardised 25(OH)D levels ${ }^{(65-67)}$, and all were conducted as part of the ODIN project ${ }^{(68)}$. It was suggested recently that unstandardised results might end up providing the same answer as standardised data ${ }^{(69)}$. However, given the amount of assay variability that exists, without standardisation, we will never know if the results are correct. In today's evidence-based world, guidelines and policy simply cannot be made based on serendipity. In summary, without accurate and precise data, countries with current guidelines committees are stuck in place, and other agencies/medical societies wanting to develop guidelines appear to be selecting one set of guidelines or the other without the data needed to resolve the differences. That means that without accurate and precise data, there is an inadequate basis to advance the vitamin D field and establish if $25(\mathrm{OH}) \mathrm{D}$ increases or decreases the risk of non-skeletal diseases. Thus, the paralysis that has ensued expands and worsens.

\section{VDSP: a ready solution}

The National Institutes of Health (NIH) Office of Dietary Supplements (ODS) established the VDSP in 2010 and coordinated its efforts until 2018. Since 2018 it has been coordinated as an independent agency. From the beginning, VDSP has been an international collaborative effort to standardise the laboratory measurement of serum total $25(\mathrm{OH}) \mathrm{D}$ and other potential markers of vitamin D status in order to improve clinical and public health practice ${ }^{(6,70)}$.

A standardised laboratory measurement is defined as one that provides the 'true' total $25(\mathrm{OH}) \mathrm{D}$ concentration as measured by the three JCTLM-recognised reference measurement procedures ${ }^{(71)}$. Serum $25(\mathrm{OH}) \mathrm{D}$ measurements can be 'prospectively' standardised using a standardised assay, or they can be 'retrospectively' standardised, after the fact, using methods developed by the $\operatorname{VDSP}^{(14,72,73)}$.

Two examples from representative national surveys highlight the importance of having standardised $25(\mathrm{OH})$ $\mathrm{D}$ data to evaluate current levels, trends and seasonal differences in both representative national health surveys and vitamin D research. The first example is from the US National Health and Nutrition Examination Surveys (NHANES). In four surveys from 1988 to 2006, there appeared to be a dramatic drop in mean serum 25(OH)D levels for all persons aged $>12$ based on the original assay measurements (Fig. 4). DiaSorin Radioimmunoassay was used originally in all four surveys. At the time it could not be determined if the trend was real or not. However, when VDSP methods were used to retrospectively standardise the results for all four surveys, it became clear that the 'decline' was an assay $\operatorname{artefact}^{(74)}$.

The second example is from the 2011-2012 Australian Health Survey (AHS) where it was found that the prevalence of vitamin D deficiency, that is, $<20 \mathrm{ng} / \mathrm{ml}$ or



Fig. 3 Vitamin D meta-analyses published since 1992. Source: PubMed: https://www.ncbi.nlm.nih.gov/pubmed/ (accessed September 2019) 


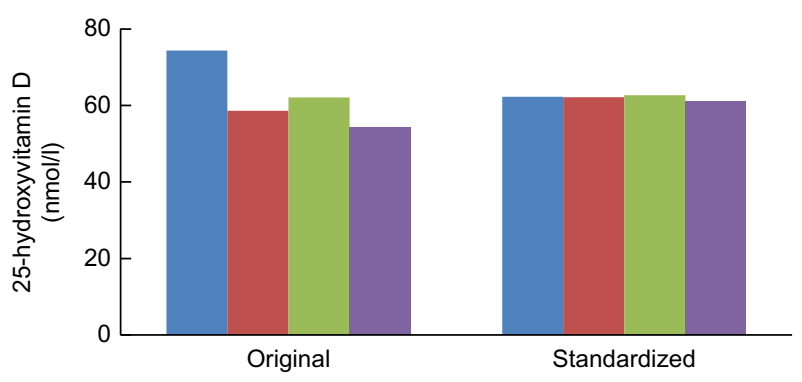

Fig. 4 Trends in original assay and standardised mean 25hydroxyvitamin D concentrations in nmol/l, USA, 1988-2006 (National Health and Nutrition Examination Surveys: 19881994, 2001-2002, 2003-2004 and 2005-2006. Survey-specific weighting factors were used to calculate representative means for the entire USA in each survey period. Standardised means were based on model 1 results. Please see source for more details. Source: Schleicher et al. ${ }^{(14)}(\square, 1988-1994$; $\square, 2001-$ 2002; п, 2003-2004; п, 2005-2006)

$50 \mathrm{nmol} / 1$, increased dramatically in winter months compared to summer months ${ }^{(75,76)}$ (Figs 5 and 6). Because serum $25(\mathrm{OH}) \mathrm{D}$ was measured with a prospective VDSP-standardised LC-MS/MS assay, it is now possible for national and state governments to develop policy and cost estimates for programmes to ameliorate the situation based on accurate and precise estimates of current $25(\mathrm{OH}) \mathrm{D}$ levels and the prevalence of deficiency by region, age, sex, ethnic group and other potential risk factors $^{(77)}$. Countries without representative standardised $25(\mathrm{OH}) \mathrm{D}$ data can only guess in the development of vitamin $\mathrm{D}$ policy, programmes and their costs, which can further lead to a loss of political support for national surveys.

Two important questions are then: (1) how to select an assay; and (2) what are the key phases in VDSP.

VDSP criteria for selecting an assay are the following:

1. Fit for use;

2. Certified by the CDC Vitamin D Standardization Certification Program as being standardised ${ }^{(78)}$ and having an appropriate measurement range or be a documented standardised laboratory-developed HPLC or LC-MS/MS assay with an appropriate measurement range;

3. Appropriate level of assay precision and accuracy; and

4. Meets VDSP assay standardisation criteria in your 'hands' or laboratory.

'Fit for use' is a new criterion and has been added with the realisation that some immunoassays do not function appropriately in all patient populations ${ }^{(79)}$. It means that the assay chosen will perform appropriately and provide standardised measurements in the patient/study populations in the conditions for which it will be used. This criterion applies solely to non-chromatography-based immunoassays. Depending on the situation, you may need an assay that measures serum $25(\mathrm{OH}) \mathrm{D}_{2}$ and $25(\mathrm{OH}) \mathrm{D}_{3}$

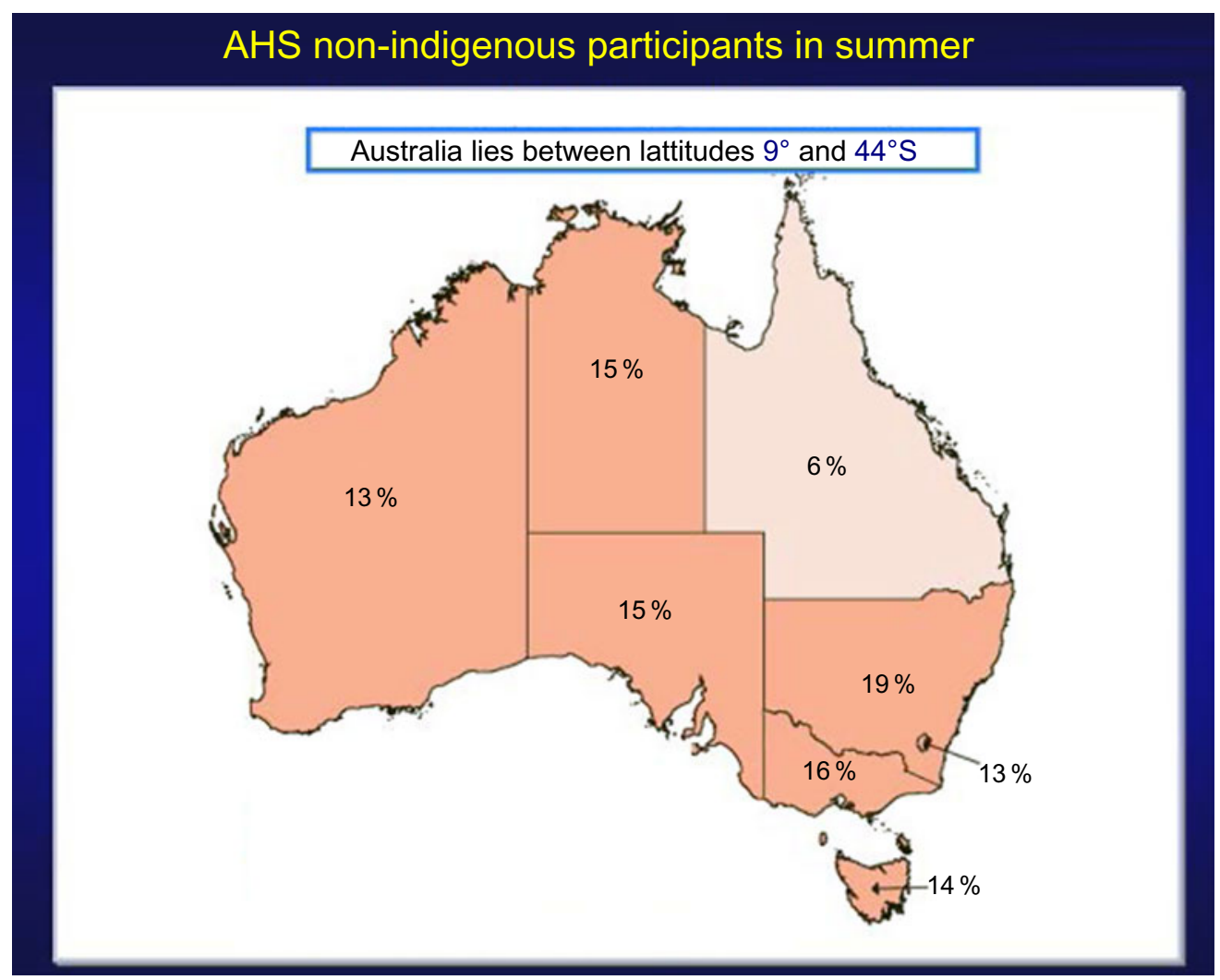

Fig. 5 Prevalence of vitamin D deficiency in Australian summer months (serum 25(OH)D concentration $<20 \mathrm{ng} / \mathrm{ml}(50 \mathrm{nmol} / \mathrm{l})$; survey weighting factors were used to calculate representative prevalence figures for each state or territory). Australian Health Survey nonindigenous participants by state and territory, Australia, 2011-2012. Source: Australian Bureau of Statistics ${ }^{(75)}$ ( $\square, 10 \%$; $\square, 10$ to $<20 \%$; , 20 to $<30 \%$; , 30 to $<40 \%$; $\square, 40$ to $<50 \%$ ) 


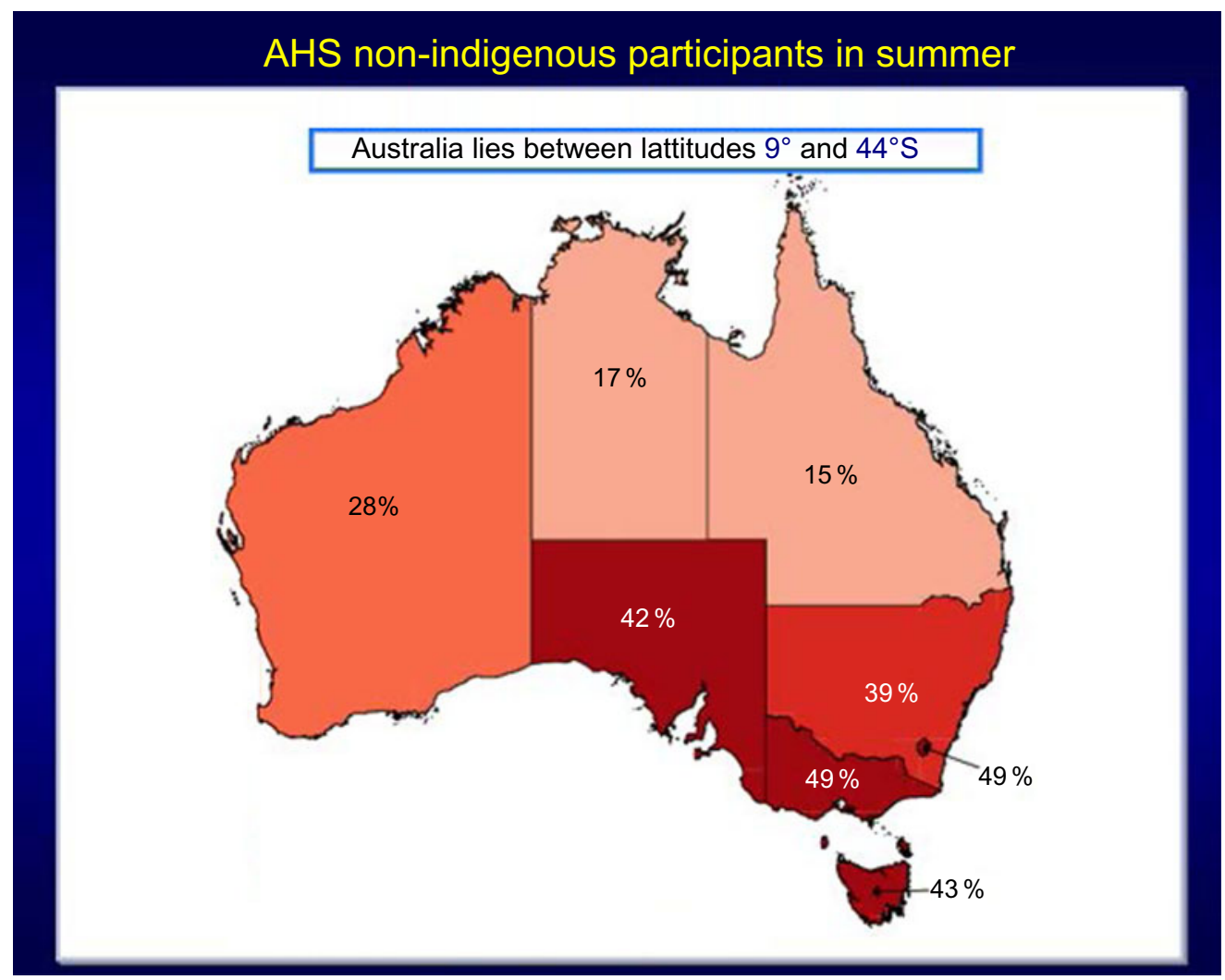

Fig. 6 Prevalence of vitamin D deficiency in Australian winter months (serum 25(OH)D concentration $<20 \mathrm{ng} / \mathrm{ml}(50 \mathrm{nmol} / \mathrm{l})$; survey weighting factors were used to calculate representative prevalence figures for each state or territory). Australian Health Survey nonindigenous participants by state and territory. Australia, 2011-2012. Source: Australian Bureau of Statistics ${ }^{(75)}$ ( $\square, 10 \%$; $\square, 10$ to $<20 \%$; $\square, 20$ to $<30 \%$; , 30 to $<40 \%$; , 40 to $<50 \%$ )

accurately, or you may need one that measures total $25(\mathrm{OH}) \mathrm{D}$ in specific conditions, for example, pregnancy or in different pathophysiological states. Importantly, some immunoassays do not function well in pregnant women or in people with different diseases ${ }^{(79)}$. Additionally, data suggest that some immunoassays do not measure serum $25(\mathrm{OH}) \mathrm{D}_{2}$ well $^{(79,80)}$. This can be a problem when ergocalciferol (vitamin $\mathrm{D}_{2}$ ) is used to treat vitamin D deficiency, as is the case in the USA or is used by vegetarians. It is apparent that if an assay cannot be verified to be fit for use, it should not be utilised.

If you are planning to select an immunoassay, we suggest that you first see which ones are currently, or have been in the past, certified by the CDC as meeting VDSP performance criteria of having a total $\mathrm{CV} \leq 10 \%$ and a mean bias with the range of -5 to $+5 \%^{(72,74)}$. The list of current and past CDC-certified assays is available from the CDC website: https://www.cdc.gov/labstandards/hs.html.

The CDC list also gives information on the assays' stated measurement range. VDSP recommends using an assay that does have an appropriate measurement range for the population it will be used in; for example, it should be able to measure $25(\mathrm{OH}) \mathrm{D}$ in persons who are deficient.

Representative national nutrition surveys need to have the very highest level of accuracy and precision. Therefore, it has been recommended that a standardised LC-MS/MS assay be selected ${ }^{(81)}$.

There is another reason for national health surveys and researchers to consider using an LC-MS/MS assay. At present, the vitamin D field is in a great deal of flux where additional vitamin $\mathrm{D}$ metabolites, for example, 3-epi-25(OH) $\mathrm{D}_{3}, 24 \mathrm{R}, 25(\mathrm{OH})_{2} \mathrm{D}_{3}$ and vitamin D-binding protein (VDBP), may turn out to be essential to assessing vitamin D status $^{(82,83)}$. For national health surveys to maintain political support, they need to be flexible enough to respond to the needs that were not anticipated at the time the survey was designed. As a result, we suggest that, if possible, it would be prudent to measure $25(\mathrm{OH}) \mathrm{D}_{2}, 25(\mathrm{OH}) \mathrm{D}_{3}$, 3-epi-25(OH)D $3,24 \mathrm{R}, 25(\mathrm{OH})_{2} \mathrm{D}_{3}$ and possibly VDBP as well in those surveys. Given that researchers around the world are generally working with very limited budgets, we suggest that research grant applications include measurement of those compounds where it fits in with the hypotheses being tested and, otherwise, request funds to collect and appropriately store serum samples for potential future analyses.

It is possible to standardise the measurements for those analytes and $25(\mathrm{OH}) \mathrm{D}$ to $24 \mathrm{R}, 25(\mathrm{OH})_{2} \mathrm{D}_{3}$ ratio and VDBP as well given that there are reference methods and reference materials available ${ }^{(27,84-86)}$. NIST SRMs 972a, 1949 and 
Table 4 Reference values for Standard Reference Material ${ }^{\circledR}$ 1949: Frozen Human Prenatal Serum*

\begin{tabular}{|c|c|c|c|c|c|c|c|c|}
\hline \multirow[b]{3}{*}{ Constituent† } & \multicolumn{8}{|c|}{ Group } \\
\hline & \multicolumn{2}{|c|}{ Non-pregnant } & \multicolumn{2}{|c|}{ First trimester } & \multicolumn{2}{|c|}{ Second trimester } & \multicolumn{2}{|c|}{ Third trimester } \\
\hline & Mean & $\begin{array}{l}\text { Expanded } \\
\text { uncertainty }\end{array}$ & Mean & $\begin{array}{l}\text { Expanded } \\
\text { uncertainty }\end{array}$ & Mean & $\begin{array}{l}\text { Expanded } \\
\text { uncertainty }\end{array}$ & Mean & $\begin{array}{l}\text { Expanded } \\
\text { uncertainty }\end{array}$ \\
\hline $25(\mathrm{OH}) \mathrm{D}_{3}(\mathrm{ng} / \mathrm{ml})$ & 24.98 & 0.28 & $26 \cdot 01$ & 0.22 & $30 \cdot 00$ & 0.50 & $29 \cdot 43$ & 0.41 \\
\hline $25(\mathrm{OH}) \mathrm{D}_{2}(\mathrm{ng} / \mathrm{ml})$ & N/A & & $\mathrm{N} / \mathrm{A}$ & & 0.514 & 0.037 & 0.897 & 0.057 \\
\hline 3-epi-25(OH)D $\mathrm{D}_{3}(\mathrm{ng} / \mathrm{ml})$ & 1.32 & 0.06 & 1.20 & 0.05 & 1.87 & 0.07 & 1.87 & 0.04 \\
\hline $\operatorname{VDBP}(\mu \mathrm{g} / \mathrm{ml})$ & 211.5 & $2 \cdot 8$ & $286 \cdot 7$ & $3 \cdot 8$ & $349 \cdot 7$ & 4.3 & 383.4 & $5 \cdot 1$ \\
\hline $\operatorname{VDBP}(\mu \mathrm{mol} / \mathrm{kg})$ & 4.01 & 0.05 & 5.43 & 0.06 & $6 \cdot 64$ & 0.07 & $7 \cdot 28$ & 0.08 \\
\hline
\end{tabular}

3-epi-25(OH) $\mathrm{D}_{3}$, 3-epi-25-hydroxyvitamin $\mathrm{D}_{3}$; VDBP, vitamin D-binding protein.

${ }^{*}$ Additional target values given for measures of thyroid function, as well as for copper, selenium and zinc. For additional details, see National Institute for Standards and Technology. Certificate of Analysis Standard Reference Material ${ }^{\circledR}$ 1949: Frozen Human Prenatal Serum.

†Equations to convert from $\mathrm{ng} / \mathrm{ml}$ to nmol/l: (1) $25(\mathrm{OH}) \mathrm{D}_{3}: 2.496 \times \mathrm{ng} / \mathrm{ml} ;(2) 25(\mathrm{OH}) \mathrm{D}_{2}: 2.423 \times \mathrm{ng} / \mathrm{ml} ;(3) 3-\mathrm{epi}-25(\mathrm{OH}) \mathrm{D}_{3}: 2 \cdot 496 \times \mathrm{ng} / \mathrm{ml}$.

$\ddagger$ No concentration value provided in the Certificate of Analysis.

2973 along with selected DEQAS samples provide target values for $25(\mathrm{OH}) \mathrm{D}_{2}, 25(\mathrm{OH}) \mathrm{D}_{3}, 3$-epi-25(OH)D $\mathrm{D}_{3}$ and $24 \mathrm{R}, 25(\mathrm{OH})_{2} \mathrm{D}_{3}{ }^{(14,87,88)}$. NIST SRM 1949 includes target values for VDBP (Table 4$)^{(88)}$. However, at present, VDSP statistical criteria to define standardisation/traceability for those compounds have not been defined. Currently, the VDSP and the International Federation of Clinical Chemistry and Laboratory Medicine are collaborating to define those statistical criteria.

To accomplish assay standardisation, we recommend the following two-phase approach:

- Phase 1: verification of fit for use

- Phase 2: calibration of assay to meet VDSP criteria, that is, total $\mathrm{CV}<10 \%$ and mean bias $\pm 5 \%^{(14,72)}$.

Verification of fit for use can be accomplished by testing the assay against a VDSP standardised LC-MS/MS assay. On the other hand, NIST SRM 1949 includes reference measurement target values in sera from pregnant women in the first, second and third trimesters and should be used to verify that the intended assay is 'fit for use' in pregnant women (Table 4) ${ }^{(88)}$.

An essential point that needs repeating is that laboratories cannot assume that just because an immunoassay assay is CDC-certified it will function appropriately in their hands ${ }^{(89,90)}$. We recommend a testing period in order to verify that an immunoassay is standardised especially since there is generally very little an individual laboratory can do to 'calibrate' an immunoassay.

If we started today to conduct all vitamin $\mathrm{D}$ research using only assays that were both 'fit for use' and VDSPstandardised, would we be able to decide between IOM 2011 and Endocrine Society guidelines (Table 3)? The sad fact is that we could not, until substantial amounts of new, standardised data are available. Since the discovery of serum $25 \mathrm{OHD}_{3}$ in $1968^{(91)}$, approximately 80000 vitamin D papers have been published (Fig. 7). Virtually all of those, where serum total $25(\mathrm{OH}) \mathrm{D}$ was measured, reported only

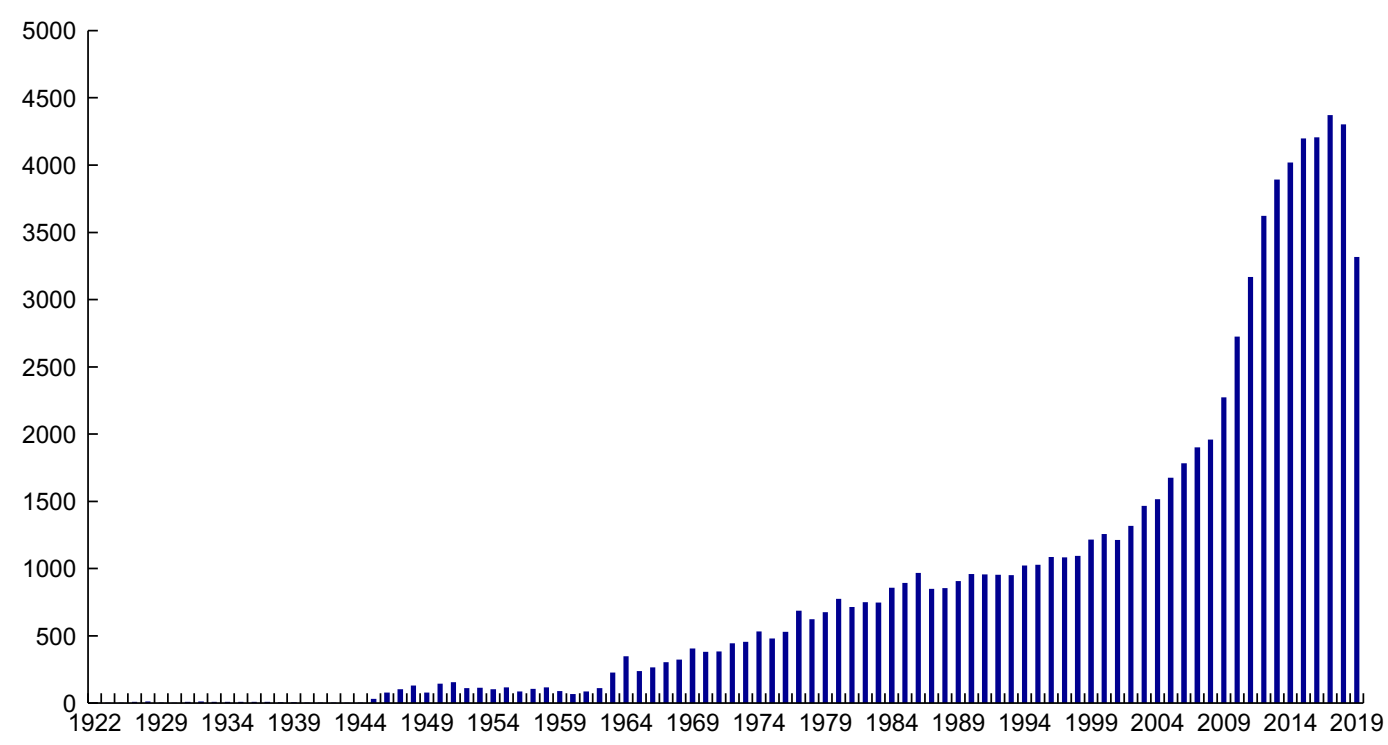

Fig. 7 Vitamin D papers published since 1922. Source: PubMed: https://www.ncbi.nlm.nih.gov/pubmed/ (accessed September 2019) 
unstandardised data. As a result, we recommend that the vitamin D field needs to work with researchers, journal editors and research funding agencies around the world to identify and promote keys studies for retrospective standardisation using methods and procedures developed by the $\operatorname{VDSP}^{(73,92)}$. At that point, the retrospectively standardised data could be re-analysed and published in meta-analyses based solely on standardised results ${ }^{(93)}$.

Importantly, retrospective standardisation can be accomplished relatively inexpensively as shown in the re-analyses of the Canadian Health Measures and HunMen study data $^{(12,94)}$. Such approaches could be utilised in virtually all vitamin D research. Journal editors are encouraged to require either 'prospectively' standardised or 'retrospectively' standardised $25(\mathrm{OH}) \mathrm{D}$ data as a condition for publication.

We recognise that all science evolves. Similarly, there are weaknesses in the current VDSP performance criteria that will, hopefully, be improved as the vitamin D field progresses. One worthy of brief mention is the VDSP performance criteria for mean bias ${ }^{(74)}$. Nonetheless, we believe it is past time to implement the recommendations laid out here.

\section{Conclusions}

It is past time for the vitamin $\mathrm{D}$ research field to embrace reporting only standardised $25(\mathrm{OH}) \mathrm{D}$ data. The assays utilised must be: (1) fit for use in the population studied; and (2) standardised (either prospectively or retrospectively) across the appropriate measurement range. Moreover, funding agencies, for example, the US NIH, and journals must make this essential for study funding and publication. Failure to do so will perpetuate the current paralysis and preclude moving the vitamin D field forward.

\section{Acknowledgements}

Acknowledgements: The authors would like to thank Dr. Mona S. Calvo, Dr. Peter J. Gergen and Mr. Lawrence Kessenich for reading and very kindly providing thoughtful comments and suggestions to an early draft. Figures 1 and 2 are being used with the permission of Nature Reviews Endocrinology and Pediatrics, respectively. Conflict of interest: C.T.S.: The NIH/ODS established the VDSP in December 2010 and supported it through April 2018. Dr. C.T.S. coordinated the VDSP throughout that entire time period as an NIH employee and then, after his retirement, as a consultant to NIH/ODS. Since April 2018, Dr. C.T.S. has continued to coordinate the VDSP privately in order to fulfil its goal of promoting standardised measurement of vitamin D status in order to improve clinical and public health practice worldwide. N.B. has no conflicts of interest. Financial support: This research received no specific grant from any funding agency in the public, commercial or not-for-profit sectors. Authorship: Formulating commentary outline:
C.T.S. and N.B. Data analyses: C.T.S. Writing article: C.T.S. and N.B. Reviewing article: C.T.S. and N.B.

CT Sempos ${ }^{1}$ and N Binkley ${ }^{2}$

${ }^{1}$ Vitamin D Standardization Program LLC,

Havre de Grace, MD, USA

Emailsemposch@gmail.com

${ }^{2}$ Osteoporosis Clinical Research Program and Institute on Aging, Department of Medicine, University of

Wisconsin-Madison,

Madison, WI, USA

\section{References}

1. Bouillon R (2017) Comparative analysis of nutritional guidelines for vitamin D. Nat Rev Endocrinol 13, 466-479.

2. Pilz S, Zitterman A, Trummer C et al. (2019) Vitamin D testing and treatment: a narrative review of current evidence. Endocr Connect 8, R27-R43.

3. Lucas RM, Gorman S, Black L et al. (2017) Clinical, research, and public health implications of poor measurement of vitamin D status. J AOAC Int 100, 1225-1229.

4. Calvo MS \& Lamberg-Allardt CJ (2017) Vitamin D research and public health nutrition: a current perspective. Public Health Nutr 20, 1713-1717.

5. Calvo MS (2019) Monitoring vitamin D status and intake in the US population: essential to understand the role of vitamin D in health. Am J Clin Nutr 110, 6-7.

6. Sempos CT, Vesper HW, Phinney KW et al. (2012) Vitamin D status as an international issue: national surveys and the problem of standardization. Scand J Clin Lab Invest 72, Suppl. 243, 32-40.

7. Binkley N, Krueger D, Cowgill CS et al. (2004) Assay variation confounds the diagnosis of hypovitaminosis $\mathrm{D}$ : a call for standardization. J Clin Endocrinol Metab 89, $3152-3157$.

8. Carter GD (2011) Accuracy of 25-hydroxyvitamin D assays: confronting the issues. Curr Drug Targets 12, 19-28.

9. SA Wise, KW Phinney, SS-C Tai et al. (2017) Baseline assessment of 25-hydroxyvitamin D assay performance - a Vitamin D Standardization Program (VDSP) Study. J AOAC Int 100, 1244-1252.

10. Rahme M, Al-Sheer L Singh R et al. (2018) Limitations of platform assays to measure serum 25OHD level impact on guidelines and practice decision making. Metabolism 89, $1-7$.

11. Australian Bureau of Statistics (2013) Australian Health Survey: Users Guide, 2011-13. https://www.abs.gov.au/ AUSSTATS/abs@.nsf/Lookup/4363.0.55.001Main+Features 12011-13 (accessed November 2019).

12. Serafin K, Durazo-Arvizu R, Tian L et al. (2015). Standardizing 25-hydroxyvitamin D values from the Canadian Health Measures Survey. Am J Clin Nutr 102, 1044-1055.

13. Cashman KD, Kiely M, Kinsella M et al. (2013) An evaluation of the Vitamin D Standardization Program protocols for standardizing serum 25-hydroxyvitamin D data: a case study of the program's potential for National Nutrition/Health Surveys. Am J Clin Nutr, 97, 1234-1242.

14. Schleicher RL, Sternberg MR, Lacher DA et al. (2016) A method-bridging study for serum 25-hydroxyvitamin D to standardize historical radioimmunoassay data to liquid chromatography-tandem mass spectrometry. Natl Health Stat Report 1-16. 
15. Cashman KD, Holvik K, Andersen R et al. (2015) Standardizing serum 25-hydroxyvitamin D data from four Nordic population samples using the Vitamin D Standardization Program protocols: shedding new light on vitamin D status in Nordic individuals. Scand J Clin Lab Inves 75, 549-561.

16. Cashman KD, Dowling KG, Škrabáková Z et al. (2016) Vitamin D deficiency in Europe: pandemic? Am J Clin Nutr 103, 1033-1044.

17. Department of Health (1991) Dietary Reference Values for Food Energy and Nutrients for the United Kingdom. Report of the Panel on Dietary Reference Values of the Committee on Medical Aspects of Food Policy. London: The Stationary Office.

18. Arnaud SB, Stickler GB \& Haworth JC (1976) Serum 25-hydroxyvitamin D in infantile rickets. Pediatrics 57, 221-225.

19. Department of Health (1998) Nutrition and Bone Health: with Particular Reference to Calcium and Vitamin D. Report of the Subgroup on Bone Health, Working Group on the Nutritional Status of the Population of the Committee on Medical Aspects of Food and Nutrition Policy. London: The Stationery Office.

20. Grindulis H, Scott PH, Belton NR et al. (1988) Combined deficiency of iron and vitamin D in Asian toddlers. Arch Dis Child 61, 843-848.

21. Scientific Advisory Committee on Nutrition (SACN) (2016) Vitamin D and Health. https:/www.gov.uk/government/ groups/scientific-advisory-committee-on-nutrition (accessed October 2019).

22. Jongen MJ, van der Vijgh WJ, van Beresteyn EC et al (1982) Interlaboratory variation of vitamin D1) metabolite measurements. J Clin Chem Clin Biochem 20, 753-756.

23. Jongen MJ, Van Ginkel FC, van der Vijgh WJ et al. (1984) An international comparison of vitamin D metabolite measurements. Clin Chem 30, 399-403.

24. Mayer E \& Schmidt-Gayk H (1984) Interlaboratory comparison of 25-Hydroxyvitamin D determination. Clin Chem 30, 1199-1204.

25. Le Goff C, Cavalier E, Souberbielle J-C et al. (2015) Measurement of circulating 25-hydroxyvitamin D: a historical review. Pract Lab Med 2, 1-14.

26. Carter GD, Berry J, Durazo-Arvizu R et al. (2018) Hydroxyvitamin D assays: an historical perspective from DEQAS. J Steroid Biochem Mol Biol 177, 30-35.

27. Tai SSC, Bedner M \& Phinney KW (2010) Development of a candidate reference measurement procedure for the determination of 25-hydroxyvitamin $\mathrm{D}_{3}$ and 25-hydroxyvitamin $\mathrm{D}_{2}$ in human serum using isotope-dilution liquid chromatography-tandem mass spectrometry. Anal Chem 82, 19421948.

28. Mineva EM, Schleicher RL, Chaudhary-Webb M et al. (2015) A candidate reference measurement procedure for quantifying serum concentrations of 25-hydroxyvitamin $D(3)$ and 25-hydroxyvitamin D(2) using isotope-dilution liquid chromatography-tandem mass spectrometry. Anal Bioanal Chem 407, 5615-5624.

29. Heureaux N (2017) Vitamin D testing - where are we and what is on the horizon? In Advances in Clinical Chemistry, $\mathbf{7 8}$, pp. 59-101 [GS Makowski, editor]. Burlington: Academic Press.

30. Atef SH (2018) Vitamin D assays in clinical laboratory: past, present and future challenges. J Steroid Biochem Mol Biol 175, 136-137.

31. Erdman P, Palmer-Toy DE, Horowitz G et al. (2019) Accuracy-based vitamin D survey: six years of quality improvement guided by proficiency testing. Arch Pathol Lab Med 143, 1531-1538.

32. Black LJ, Anderson D, Clarke MW et al. (2015) Analytical bias in the measurement of serum 25-Hydroxyvitamin D concentrations impairs assessment of Vitamin D status in clinical and research settings. PLoS One 10, e0135478.

33. Institute of Medicine Food and Nutrition Board (1997) Dietary Reference Intakes for Calcium, Phosphorus, Magnesium, Vitamin D, and Fluoride. Washington, DC: National Academy Press.

34. Specker BL, Ho ML, Oestreich A et al. (1992) Prospective study of vitamin D supplementation and rickets in China. $J$ Pediatr 120, 733-739.

35. Institute of Medicine (US) (2011) Committee to Review Dietary Reference Intakes for Calcium and Vitamin D. Washington, DC: National Academies Press.

36. Yetley EA, Brulé D, Cheney MC et al. (2009) Dietary reference intakes for vitamin D: justification for a review of the 1997 values. Am J Clin Nutr 89, 719-727.

37. Nordic Council of Ministers (2012) Nordic Nutrition Recommendations (2012) Integrating Nutrition and Physical Activity. https://www.norden.org/en/publication/ nordic-nutrition-recommendations-2012 (accessed October 2019).

38. Federal Commission for Nutrition (2012) Vitamin D Deficiency: Evidence, Safety, and Recommendations for the Swiss Population. Expert report of the FCN. Zurich: Federal Office for Public Health.

39. European Food Safety Authority panel on dietetic products, nutrition, and allergies (2016) Scientific opinion on dietary reference values for vitamin D. EFSA J 14, 4547.

40. Health Council of the Netherlands (2012) Evaluation of dietary reference values for Vitamin D. Health Council of the Netherlands: the Hague publication no. 2012/15E.

41. Misra M, Pacaud D, Petryk A et al. (2008) Drug and therapeutics committee of the Lawson Wilkins pediatric endocrine society. Vitamin D deficiency in children and its management: review of current knowledge and recommendations. Pediatrics 122, 398-417.

42. German Nutrition Society (2012) New reference values for vitamin D. Ann Nutr Metab 60, 241-246.

43. Nowson CA, McGrath JJ, Ebeling PR et al. (2012) Vitamin D and health in adults in Australia and New Zealand: a position statement. Med J Aust 196, 686-687.

44. Paxton GA, Teale GR, Nowson CA et al. (2013) Vitamin D and health in pregnancy, infants, children and adolescents in Australia and New Zealand: a position statement. Med J Aust 198, 142-143.

45. Arundel P, Ahmed SF, Allgrove J et al. (2012) British paediatric and adolescent bone group's position statement on vitamin D deficiency. BMJ 345, e8182.

46. Vidailhet M, Mallet E, Bocquet A et al. (2012) Vitamin D: still a topical matter in children and adolescents. A position paper by the committee on nutrition of the French Society of Paediatrics. Arch Pediatr 19, 316-328.

47. Martínez Suárez V, Moreno Villares JM, Dalmau Serra J et al. (2012) Recommended intake of calcium and vitamin D: positioning of the nutrition committee of the AEP. An Pediatr 77, 57. e1-e8.

48. Braegger C, Campoy C, Colomb V et al. (2013) Vitamin D in the healthy European paediatric population. I Pediatr Gastroenterol Nutr 56, 692-701.

49. Wagner CL \& Greer FR (2008) Prevention of rickets and Vitamin D deficiency in infants, children, and adolescents. Pediatrics 122, 1142-1152.

50. Golden NH, Abrams SA \& Committee on Nutrition (2014) Optimizing bone health in children and adolescents. Pediatrics 134, e1229-e1243.

51. Munns CF, Shaw N, Kiely M et al. (2016) Global consensus recommendations on prevention and management of nutritional rickets. J Clin Endocrinol Metab 101, 394-415.

52. Holick MF, Binkley NC, Bischoff-Ferrari HA et al. (2011) Evaluation, treatment, and prevention of vitamin D 
deficiency: an Endocrine Society clinical practice guideline. J Clin Endocrinol Metab 96, 1911-1930.

53. Canadian Paediatric Society (2007) Vitamin D supplementation: recommendations for Canadian mothers and infants. Paediatr Child Health 12, 583-598.

54. Dawson-Hughes B, Mithal A, Bonjour J-P et al. (2010) IOF position statement: vitamin $\mathrm{D}$ recommendations for older adults. Osteoporos Int 21, 1151-1154.

55. Papaioannou A, Morin S, Cheung AM et al. (2015) Recommendations for preventing fracture in long-term care. CMAJ 187, 1135-1144.

56. Płudowski P, Karczmarewicz E, Bayer M et al. (2013) Practical guidelines for the supplementation of vitamin $\mathrm{D}$ and the treatment of deficits in Central Europe - recommended vitamin D intakes in the general population and groups at risk of vitamin deficiency. Endokrynol Pol 64, 319-327.

57. Society for Adolescent Health and Medicine (2013) Recommended vitamin D intake and management of low vitamin D status in adolescents: a position statement of the society for adolescent health and medicine. I Adolesc Health 52, 801-803.

58. American Geriatrics Society Workshop on Vitamin D Supplementation for Older Adults (2014) Recommendations abstracted from the American geriatrics society consensus statement on Vitamin D for prevention of falls and their consequences. J Am Geriatr Soc 62, 147-152.

59. Cosman F, de Beaur SJ, LeBoff MS et al. (2014) Clinician's guide to prevention and treatment of osteoporosis. Osteoporos Int 25, 2359-2381.

60. Baggerly CA, Cuomo RE, French CB et al. (2015) Sunlight and vitamin D: necessary for public health. J Am Coll Nutr 34, 359-365.

61. Haq A, Wimalawansa SJ, Pludowski P et al. (2016) Clinical practice guidelines for vitamin $\mathrm{D}$ in the United Arab Emirates. J Steroid Biochem Mol Biol 175, 4-11.

62. Okazaki R, Ozono K, Fukumoto S et al. (2017) Assessment criteria for vitamin D deficiency/insufficiency in Japan: proposal by an expert panel supported by the research program of intractable diseases, Ministry of Health, Labour and Welfare, Japan, the Japanese Society for Bone and Mineral Research and the Japan Endocrine Society [opinion]. $J$ Bone Miner Metab 35, 1-5.

63. Saggese G, Vierucci F, Prodam F et al. (2018) Vitamin D in pediatric age: consensus of the Italian Pediatric Society and the Italian Society of Preventive and Social Pediatrics, jointly with the Italian Federation of Pediatricians. Ital $J$ Pediatr 44, 51.

64. Holick MF (2007). Vitamin D deficiency. N Engl J Med 357, 266-281.

65. Cashman KD, Ritz C; Kiely M et al. (2017) Improved dietary guidelines for Vitamin D: application of Individual Participant Data (IPD)-level meta-regression analyses. Nutrients 9, pii: E469. doi: 10.3390/nu9050469.

66. Gaksch M, Jorde R, Grimnes G et al. (2017) Vitamin D and mortality: an individual participant data meta-analysis of standardized 25-hydroxyvitamin D in 26,916 individuals of a European consortium. PLoS One 12, e0170791.

67. Swart KMA, Lips P, Brouwer IA et al. (2018). The effects of vitamin D supplementation on markers for cardiovascular disease and diabetes mellitus: an individual participant data meta-analysis of randomized controlled trials. AJCN 107, 1043-1053.

68. Kiely M, Cashman KD \& on behalf of the ODIN Consortium (2015). The ODIN project: development of food-based approaches for prevention of vitamin D deficiency throughout life. Nutr Bull 40, 235-246.

69. Cashman KD (2018) Vitamin D requirements for the future lessons learned and charting a path forward. Nutrients $\mathbf{1 0}$, pii: E533. doi: 10.3390/nu10050533.
70. Binkley N \& Sempos CT (2014) Standardizing vitamin D assays: the way forward. J Bone Miner Res 29, 1709-1714.

71. Myers GL (2008) Introduction to standardization of laboratory results. Steroids 73, 1293-1296.

72. Sempos C, Betz J, Camara J et al. (2017) General steps to standardize the laboratory measurement of serum total 25-hydroxyvitamin D. J AOAC Int 100, 1230-1233.

73. Durazo-Arvizu R, Tian L, Brooks SPJ et al. (2017) The Vitamin D Standardization Program (VDSP) manual for retrospective laboratory standardization of serum 25-hydroxyvitamin D data. J AOAC Int 100, 1234-1243.

74. Sempos CT, Heijboer AC, Bikle DD et al. (2018) Vitamin D assays and the definition of hypovitaminosis D: results from the 1st international conference on controversies in Vitamin D. Br J Clin Pharmacol 84, 2194-2207.

75. Australian Bureau of Statistics (2014) 4364.0.55.006 Australian Health Survey: Biomedical results for nutrients, 2011-12. https://www.abs.gov.au/ausstats/abs@.nsf/Lookup/ 4364.0.55.006Chapter2002011-12 (accessed November 2019).

76. Malacova E, Cheang PR, Dunlop E et al. (2019) Prevalence and predictors of vitamin D deficiency in a nationally representative sample of adults participating in the 2011-2013 Australian Health Survey. Br J Nutr 121, 894-904.

77. Jääskeläinen T, Itkonen ST, Lundqvist A et al. (2017) The positive impact of general vitamin $\mathrm{d}$ food fortification policy on vitamin D status in a representative adult finish population: evidence form an 11-y follow-up based on standardized 25-hydroxyvitamin D data. Am J Clin Nutr 105, 1512-1520.

78. Centers for Disease Control and Prevention (2019) Laboratory quality assurance and standardization programs. VDSCP: Vitamin D Standardization-Certification Program. https://www.cdc.gov/labstandards/vdscp.html (accessed November 2019).

79. Dirks NF, Ackermans MT, Pils P et al. (2018) The when, what \& how of measuring vitamin D metabolism in clinical medicine. Nutrients 10, pii: E482.

80. Garnett E, Li J, Rajapakshe D, Tam E et al. (2019). Efficacy of two vitamin D immunoassays to detect $25-\mathrm{OH}$ vitamin D2 and D3. Pract Lab Med 17, e00130.

81. de la Hunty A, Wallace AM, Gibson S et al. (2010) U.K. food standards agency workshop consensus report: the choice of method for measuring 25-hydroxyvitamin D to estimate vitamin D status for the UK National Diet and Nutrition Survey. BrJ Nutr 104, 612-619.

82. Herrmann M, Farrell C-J J, Pusceddu I et al. (2017) Assessment of vitamin D status - a changing landscape. Clin Chem Lab Med 55, 3-26.

83. Jukic AMZ, Hoofnagle AN \& Lutsey PL (2018) Measurement of vitamin D for epidemiological and clinical research: shining light on a complex decision. Am J Epidemiol 187, 879-890.

84. Tai SS \& Nelson MA 2015) Candidate reference measurement procedure for the determination of (24R), 25-Dihydroxyvitamin D3 in human serum using isotopedilution liquid chromatography-tandem mass spectrometry. Anal Chem 87, 7964-7970.

85. Kilpatrick LE \& Phinney KW (2017) Quantification of total vitamin-D-binding protein and the glycosylated isoforms by liquid chromatography-isotope dilution mass spectrometry. J Proteome Res 16, 4185-4195.

86. Dirks NF, Ackermans MT, de Jonge R et al. (2019) Reference values for 24,25 idihydroxyvitamin $\mathrm{D}$ and the 25-hydroxyvitamin $\mathrm{D} / 24,25$-dihydroxyvitamin $\mathrm{D}$ ratio. Clin Chem Lab Med 57, e259-e261.

87. Wise SA, Tai SS, Burdette CQ et al. (2017) Role of the National Institute of Standards and Technology (NIST) in Support of the National Institutes of Health, Office of Dietary Supplement Vitamin D Initiative. J AOAC Int 100, 1260-1276. 
88. National Institute of Standards and Technology (2019). Certificate of analysis. Standard reference material 1949: Frozen Human Prenatal Serum. https://www-s.nist.gov/ srmors/view_detail.cfm?srm=1949 (accessed November 2019).

89. Elsenberg EHAM, ten Boekel E, Huijgen H et al. (2017). Standardization of automated 25-hydroxyvitamn D assays: how successful is it? Clin Chem 50, 1126-1130.

90. Bjerg LN, Halgreen JR, Hansen SH et al. (2019) An evaluation of total 25-hydroxyvitamin D assay standardization: where are we today? J Steroid Biochem Mol Biol 190, 224-233.
91. Blunt JW, DeLuca HF \& Schnoes HK (1968) 25-Hydroxycholecalciferol: a biologically active metabolite of Vitamin $\mathrm{D}_{3}$. Biochemistry 7, 3317-3322.

92. Sempos CT, Durazo-Arvizu RA \& Carter GD (2017) Cost effective measures to standardize serum $25(\mathrm{OH}) \mathrm{D}$ values from completed studies. Osteoporos Int 28, 1503-1505.

93. Binkley N \& Carter GD (2017). Toward clarity in clinical vitamin D status: 25(OH)D assay standardization. Endocrinol Metab Clin N Am 46, 885-899.

94. Jakab E, Kalina E, Petho Z et al. (2017) Standardizing 25-hydroxyvitamin D data from the HunMen cohort. Osteoporos Int 28, 1653-1657. 